\title{
The Impact of Risk in Ethiopian Construction Project Performance
}

\author{
Bahiru Bewket Mitikie1, Jaeho Lee², Tai Sik Lee ${ }^{1 *}$ \\ Department of Civil and Environmental Engineering, Hanyang University, Ansan, South Korea \\ Email: bahirdire@gmail.com, engine@hanyang.ac.kr, *cmtsl@hanyang.ac.kr
}

How to cite this paper: Mitikie, B.B., Lee, J. and Lee, T.S. (2017) The Impact of Risk in Ethiopian Construction Project Performance. Open Access Library Journal, 4: e4233. https://doi.org/10.4236/oalib.1104233

Received: December 4, 2017

Accepted: December 19, 2017

Published: December 22, 2017

Copyright (๑) 2017 by authors and Open Access Library Inc.

This work is licensed under the Creative Commons Attribution International License (CC BY 4.0).

http://creativecommons.org/licenses/by/4.0/

\begin{abstract}
The overall aim of this work is to increase the understanding of risk's impact on civil work construction project performance. Then deeper understanding is expected to contribute a more effective risk management practice and, therefore, a better project output and better value for project stakeholders. The risk factors are identified from the literature review, and then data were collected by a major tool questionnaire and focused group discussions. Statistical Package for the Social Sciences (SPSS) program was used to analyze the data and generate statistical measures. For each risk factor probability of occurrence as well as consequences (impact) of their occurrence and the risk level are resulted. From the findings it concludes that the main risk factors that affect the project performance very high are equipment/material failure, labor poor productivity, the non-availability of equipment and material. The very low identified risk levels are injuries, earthquake \& winds; and land slide $\&$ rock falls. Finally as from the respondents and impact levels of risk; the analysis revealed that the risk management is not practiced very well.
\end{abstract}

\section{Subject Areas}

Civil Engineering

\section{Keywords}

Risk Management, Construction Project, Risk Analysis, Impact of Risk

\section{Introduction}

\subsection{Back Ground}

Project risk is a combination of probabilities that causes an event's appearance and the outcomes that the event produces. It has a significant impact on a con- 
struction project's performance in terms of cost, time and quality [1]. Risks and uncertainties appear in various shapes, besides, no construction project is risk free [2] and the water work construction project suffered from poor performance and a lack of control in various steps of the process due to the sector's problems. An effective use of project management techniques such as risk and value management are considered as key supporting processes and to add to them quality, cost, time and change control [3]. Many authors have reviewed problems on time performance in construction projects [4]. Accordingly [5] many construction projects fail to achieve their time, budget and quality goals. Moreover, the consequences of risk in construction industries of developing countries, including sub-Saharan region are more severe than in established Western Construction industries [1] [6]. The construction industry in Ethiopia is challenged by several problems and thus making efforts in developing the construction industry is very difficult and complex.

Housing construction project is in challenge due to lack of construction material. Bricks industry and other new material techniques must be included to satisfy quality, quantity and cost. The study on low cost enzyme brick can show, how the construction Engineers try to solve construction cost problems [7]. The underlying problems of the construction sector in Ethiopia is that the sector is not viewed and planned in an integrated manner, but rather, operates with fragmented, unrelated and often conflicting components. The result is wastage, inefficiency, and inability to plan for total development [8]. So far little comprehensive study was conducted on the assessment of construction risk on the overall performance of Construction Project in terms of time, cost, and quality. This circumstance entails the impact of construction risk is not quantified and modeled as to how to estimate the level of risk impact on the overall project performance. To mention some [9] attempts investigation that focused on evaluating the projects' procurement in terms of cost overrun and time delay. This project has not identified the risk factors that contribute towards cost overrun and time delay of the evaluated projects [10]. As a gap the study identified the cost overrun and time delay of the six sample projects that is the reflection of availability of construction risks. So it can deduced that the existing civil work projects in Ethiopia cannot be risk free and needs further evaluation to assess the impact of risk in the construction process. So the current study use qualitative approach to tackle the problems related to construction risk in Ethiopia. Accordingly, only twenty-two projects were sampled and investigated by using frequency analysis and relative importance index for the availability of construction risk management practices and impacts on the project performance respectively. Therefore, the focus of the study was to identify weather construction risk management practice is available and to assess the impact of construction risk. The main contribution of this study to enlighten how construction project is affected by improper risk management as well as to show to identify the risk factors with their impact on Ethiopian construction project. 


\subsection{Research Problem}

Lack of risk management in Construction projects is one of the major setbacks for construction projects performance in Ethiopia. It includes identification, assessment, monitoring, and sharing. As observation and impacts of risk that show from literature show the current status of risk identification, assessment, monitoring and risk sharing in is not practiced and modeled. But the future risk management practice must be developed from the western risk management practice. This is timely identification of risk, assessments of risk, monitoring and controlling to minimize the impact of risks. Even construction project risk cannot be ignored, but it can be managed, minimized, shared, transferred or accepted. The identification of their causes might lead to their reduction, possible elimination and subsequent improvement in overall project performance in civil work construction project. There is the gap between the existing situation and future state planned in civil Work Construction Project, for that the cost and time schedule for some projects was stated to show the significance of the study. On average, there is about $15.33 \%$ cost increment beyond the initially estimated cost and about $84 \%$ time overrun according to [11] if the risk factors have the delay of project more than 1 quarter, the risk level is high and if it is more a year and its impact is very high in terms of time and if it increases from $10 \%-20 \%$ cost, it is high in risk level. To put in a net shell, the study focuses on overall reduction of high risk level in terms of time, cost and quality and practice the risk management.

\section{Methodology}

Twenty two (22) selected projects were sampled by disproportionate stratified random sampling technique from the twenty nine construction projects of that were selected by more than $50 \%$ project performance status criteria. The assumption behind sampling the selected projects is project performance status. This study utilized the two types of data sources for investigating the impact of risk on the project performances. These are questionnaire and Focus Group Discussions (FGDs) as primary data sources and literature review as secondary data sources. Questionnaire survey and FGDs were used as data collection tools for this study. To elaborate, questionnaire survey was carried out on the selected twenty two (22) projects' representatives from contractor and consultants. The contents of the questionnaire survey on the project contractor and consultant are identifying the availability of risk management practices and impact of construction risk on the project performance in terms of time, cost and quality. This thesis work attempts to assess the current risk management practice and impact of risk in construction project to improve the overall performance. Every attempt has been made to seek information from relevant stakeholders, and to review different standard literatures. The following frame work shows the way how the study follows (Figure 1).

The research utilizes the relative important index (RII) and percentage of 


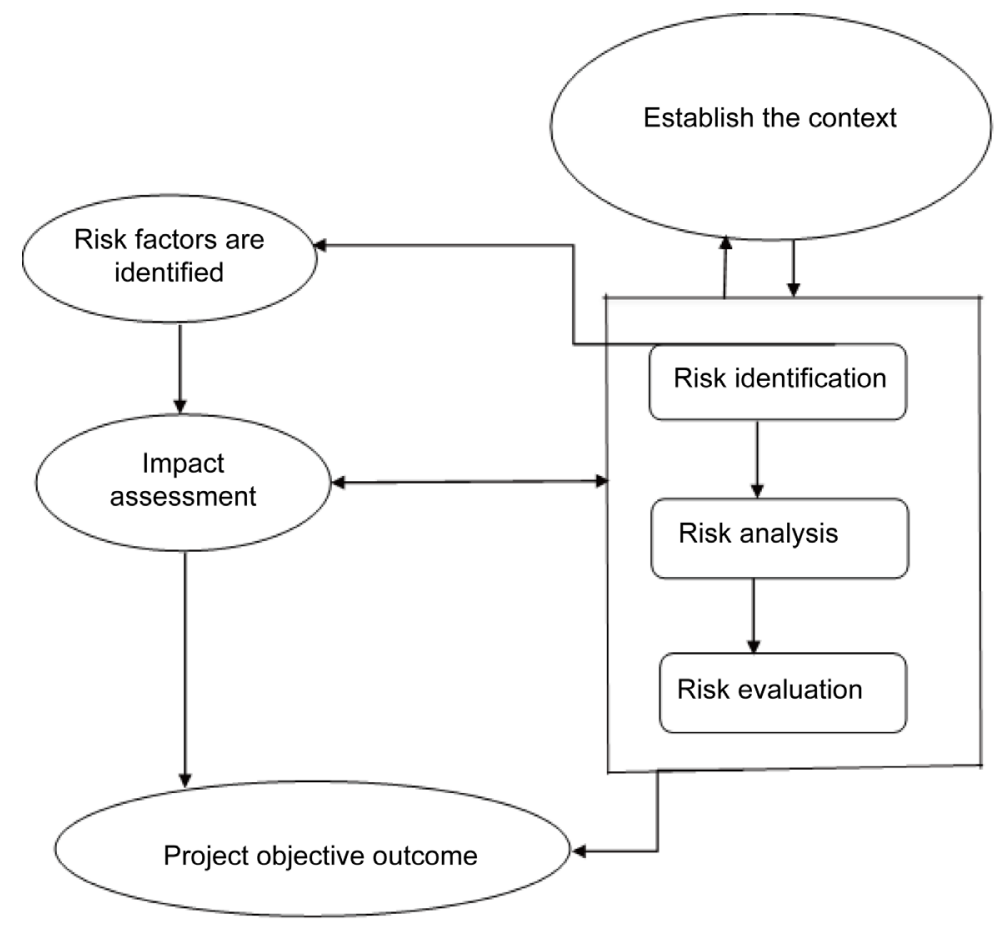

Figure 1. Model for work flow for the study.

probability from the feeding data to identify the critical attributes among all the risk factors affecting the project performance using SPSS software. Then data is presents using bar charts and pie charts; tables are selected for data presentation to show the probability of occurrence and its impact of risk factors and the radar charts are selected to present the risk level.

\section{Result and Discussion}

In general the risks level is rating based on its impact on time, cost and quality. As a combined of this consequence, the risk levels are ranked as very high, high, moderate, low and very low. Based on this rank scale the following are grouped under very high risk level.

These are equipment/material failure is ranked first in the risk level, the labour poor productivity ranked second and equipment and material availability is third. The impact is the effect of the contingency. Potential event of loss designating risk (R) is translated in mathematical terms as a result of the product of the size of the impact I and likelihood of $\mathrm{P}$ [12].

$$
\mathrm{R}=\mathrm{I} \times \mathrm{P}
$$

The risk factors indicated by the Radar graphs show the values of different risks but the same probability of occurrence and it shows the rank of risk level. Variable (Factors are the same order in above Table 1). The chart clearly shows which risk factors have high impacts from the project objectives (time, cost and time).

From the radar graph (Figure 2), Labour dispute \& strike has an impact on 
Table 1. Risk levels on impact of project objectives.

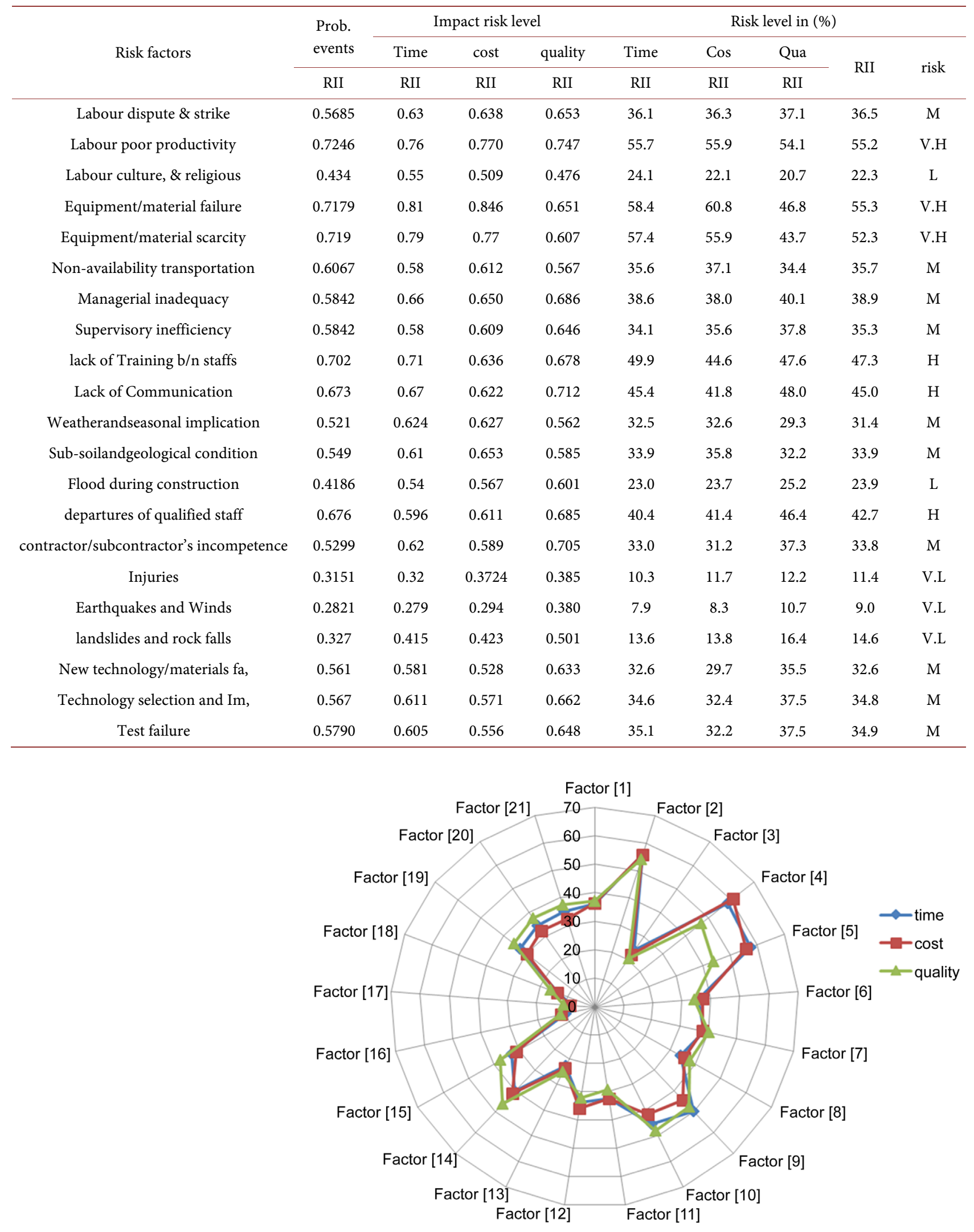

Figure 2. Risk level based on likely hood and its impact on project performance. 
more quality than others, labour poor productivity has more impact on cost, Labour culture, social \& religious background on time, Equipment/material failure on cost, Equipment/material availability on time, transportation facility on cost, Managerial inadequacy and supervisory in efficiency has more effect on quality than time and cost.

A response by all Informants to a questionnaire that inquires whether formal risk management system is in place has revealed. To answer this research question, the researcher have asked them to respond 1 , if there is risk management practice and 0 , if no risk management practices in construction project. "No formal risk management practice is in place to manage risks that may occur in Ethiopian civil work construction projects". Besides, No formal risk management plan for the projects from the consultants. In the tool of Focused group discussion, this research question has discussed in the selected focused group from design and construction section bureau. Two offices conclude that there is no risk management practice or method in Ethiopian construction project (Table 2).

\section{Conclusion}

The aim of the research is to enlighten the impact level of risk on project objectives. By developing the construction risk management practice, it enhances achievement of project objectives, there by contributing to effective implementation of the project performance. The main objective of the research is to assess the impact of risk in project time, cost and quality. From these identified risks factors those have very high risk level on project costs are equipment/material failure, labour poor productivity and equipment scarcity. Lack of training, communication is high risk level in project cost. The quality of the project affected by labour poor productivity is very high. The others like equipment/material failure, managerial inadequacy, and lack of training, lack of communication and departures of qualified staff are high risk level in term of quality. Generally very high risks are rating based on the analysis in project performance are equipment/material failure, the labour poor productivity and equipment and material non-availability, their risk level was greater than $50 \%$. The second specific objective was to identify whether water work construction project risks are managed with formal Risk management system. The assessment revealed that construction project has no routine practices employed to manage risks. Although construction risk management literature is very rich in conceptual frame

Table 2. Frequency table for Consultant's and Contractor's respondent.

\begin{tabular}{ccccccc}
\hline \multirow{2}{*}{ Value } & \multicolumn{2}{c}{ Contractor } & \multicolumn{2}{c}{ Consultant } & \multicolumn{2}{c}{ Combined results } \\
\cline { 2 - 6 } & frequency & Valid (\%) & frequency & Valid (\%) & frequency & Valid (\%) \\
\hline 0 & 15 & 78.95 & 13 & 86.67 & 28 & 82.355 \\
1 & 4 & 21.05 & 2 & 13.33 & 6 & 17.65 \\
total & 19 & 100.0 & 15 & 100.0 & 34 & 100.00 \\
\hline
\end{tabular}

$(0=$ there is no risk management practice, $1=$ There is risk management practice) . 
works and models to overcome formality of risk management efforts, number of systems which fully support risk management process is very low. The formal risk management processes which involve risk management planning, identifications, assessment, response planning, and monitoring have no model in Ethiopian construction project.

\section{Acknowledgements}

The authors would like thank the National Research Foundation of Korea for the support in finance (NRF-2011-0031645).

\section{References}

[1] Kululanga, G. and Kuotcha, W. (2010) Measuring Project Risk Management Process for Construction Contractors with Statement Indicators Linked to Numerical Scores. Engineering, Construction and Architectural Management, 17, 336-351. https://doi.org/10.1108/09699981011056556

[2] Haimes, Y.Y. (2015) Risk Modeling, Assessment, and Management, John Wiley \& Sons, Hoboken.

[3] Al-Shibly, H.H., Louzi, B. and Hiassat, M.A. (2013) The Impact of Risk Management on Construction Projects Success from the Employees Perspective. Interdisciplinary Journal of Contemporary Researches in Bussiness, 5, No. 4.

[4] Banaitiene, N. and Banaitis, A. (2012) Risk Management in Construction Projects. In: Risk Management-Current Issues and Challenges, InTech, Vilnius. https://doi.org/10.5772/51460

[5] Tsegaye, G. (2009) Design Risk Management in Ethiopian Federal Road Projects. Master's Thesis, Addis Ababa University, Addis Ababa.

[6] Wang, S.Q., Dulaimi, M.F. and Aguria, M.Y. (2004) Risk Management Framework for Construction Projects in Developing Countries. Construction Management and Economics, 22, 237-252. https://doi.org/10.1080/0144619032000124689

[7] Mitikie, B.B., Lee, T.S. and Chang, B.C. (2017) Application of Enzyme to Clay Brick and Its Effect on Mechanical Properties. KSCE Journal of Civil Engineering, 1-10. https://doi.org/10.1007/s12205-017-0533-x

[8] Ofori, G. (1993) Managing Construction Industry Development: Lessons from Singapore's Experience. NUS Press, Singapore

[9] Lema, M. (2006) Alternative Project Delivery Methods for Public Constructions: Cases in Oromia Region. Addis Ababa.

[10] Tserng, H.P., Yin, S.Y., Dzeng, R., Wou, B., Tsai, M. and Chen, W. (2009) A Study of Ontology-Based Risk Management Framework of Construction Projects through Project Life Cycle. Automation in Construction, 18, 994-1008. https://doi.org/10.1016/j.autcon.2009.05.005

[11] Hauke, J. and Kossowski, T. (2011) Comparison of Values of Pearson's and Spearman's Correlation Coefficients on the Same Sets of Data. Quaestiones Geographicae, 30, 87. https://doi.org/10.2478/v10117-011-0021-1

[12] Dumbravă, V. and Iacob, V.-S. (2013) Using Probability-Impact Matrix in Analysis and Risk Assessment Projects. Descrierea CIP/Description of CIP-Biblioteca Națională a României Conferința Internaţională Educație și Creativitate pentru o Societate Bazată pe Cunoaștere-ŞTIINŢE ECONOMICE, 42. 